\title{
Atopinis dermatitas
}

\author{
Doc. dr. Regina Ėmužytè \\ VU Medicinos fakulteto Vaikų ligų klinika
}

Reikšminiai žodžiai: atopinis dermatitas, atopinė egzema, diagnostika, gydymas.

Santrauka. Atopinis dermatitas (egzema) yra lètinė odos uždegimo liga, sukelianti stiprų niežuli ir dažniausiai prasidedanti kūdikystèje ar ankstyvoje vaikystejje. Ja serga 10-20 proc. pasaulio vaikų. Nuo jos nukenčia tiek vaikų, tiek jų tėvų gyvenimo kokybė. Atopinio dermatito patogenezės ir naujų gydymo alternatyvų sampratos evoliucija yra naudinga siekiant pagerinti šios ligos ilgalaikę kontrolę. Straipsnyje apžvelgiama nauja atopinio dermatito (egzemos) terminija ir diagnostikos duomenys. Pateikiamos naudingos gydymo rekomendacijos, paremtos ligos sunkumo laipsniu, pabrežiant profilaktikos, emolientų vartojimo ir gydymo naujais vietinio poveikio vaistais nuo alerginio uždegimo - kalcineurino inhibitoriais - reikšmę.

Atopinis dermatitas (egzema) yra lètinė odos uždegimo liga, sukelianti stiprų niežulị. Oficialios statistikos duomenimis, Lietuvoje atopinis dermatitas 2003 metais buvo diagnozuotas per 25 tūkstančiams gyventojų [1], o 2008 metais - per 22 tūkstančiams. Vaikai serga apie tris kartus dažniau nei suaugusieji. Pasaulyje atopiniu dermatitu serga 10-20 proc. vaiku pagal tarptautinio ISAAC tyrimo rezultatus [2]. Jis yra ankstyvas mažų vaikų atopijos žymuo ir vaikų astmos profilaktikos taikinys. $\mathrm{Su}$ alergine astma, alerginiu rinitu ir kitomis alerginèmis ligomis atopinis dermatitas susijęs iki 30 proc. atvejų. Nuo jo nukenčia tiek vaikų, tiek jų tẻvų gyvenimo kokybè, padaroma didelè ekonominè žala visuomenei $[3,4,5]$. Šios ligos etiologija yra daugialypè. Maisto, buitiniai, epiderminiai ir kontaktiniai alergenai sukelia nuo IgE priklausomas ir nepriklausomas nuo IgE, bet su $\mathrm{T}$ limfocitu aktyvumu susijusias reakcijas $[4,5]$. Odos uždegimą skatina dirgikliai, superantigenai (Staphylococcus aureus), autoalergenai, pažeista odos barjerinè funkcija [6]. Kasymasis (trauma) sukelia citokinų, dar labiau skatinančių niežèjimą, gamybą („ydingasis ratas"). Ligos patogenezèje labai reikšminga imuninių, genetinių, metabolinių, infekcinių, neuroendokrininių ir aplinkos veiksnių tarpusavio sąveika [1].

\section{DARBO TIKSLAS}

1. Išnagrinèti naujausius literatūros duomenis apie atopinio dermatito terminiją ir diagnostiką.

2. Pateikti naujausiais tarptautiniais sutarimais pagrịstą šiuolaikini požiūrị i atopinio dermatito gydymą.

\section{ATOPINIO DERMATITO TERMINIJA IR DIAGNOSTIKA}

Europos alergologijos ir klinikinès imunologijos akademijos siūlymu (EAACI, 2001) [7] atopiniu dermatitu vadinama ne viena atskira liga, bet grupè ligų, pasireiškiančių tam tikrais bendrais klinikiniais simptomais.
Buvo nutarta atopinio dermatito pavadinimą pakeisti nauju laikinuoju terminu - atopinès egzemos/dermatito sindromu (angl. atopic eczema/dermatitis syndrome, $A E D S)$. Kadangi atopinis dermatitas nebūtinai siejasi su atopija, po paskutinès Pasaulinès alergijos organizacijos (PAO, 2004) [8] alergijos terminu peržiūros minètą AEDS terminą nutarta pakeisti $i$ atopinès ir neatopinés egzemos terminus. Terminas atopinè egzema turètų būti vartojamas, tik tada, kai pacientas yra atopinès konstitucijos, tuo pabréžiant genetini polinkị sirgti šia liga.

Apie 20 proc. sergančiųjų atopiniu dermatitu, kuriems būdinga klasikinè klinika, nenustatoma [1, 7, 9,10]:

- padidejusio IgE kiekio serume;

- issijautrinimo maisto ar aplinkos alergenams.

Jis buvo vadinamas ivvairiai: nealerginiu, neatopiniu, nesusijusiu su IgE, endogeniniu, kriptogeniniu, konstituciniu $[7,9,10,11,12,13]$. Jam būdinga:

- atopinio dermatito klinika pagal diagnostikos kriterijus;

- nepadidejęs bendrojo IgE kiekis, nèra įsijautrinimo (IgE sukelto) maisto ir îkvepiamiesiems alergenams in vivo ir in vitro;

- nèra kitų lydinčiųjų alerginių ligų, kaip antai alerginio rinito ar astmos.

Kadangi naujausiais tyrimais įrodyti imuniniai šio atopinio dermatito fenotipo mechanizmai, manoma, kad jo vadinti nealerginiu negalima $[11,14]$. Dažniausiai atopinis dermatitas prasideda dèl alergijos maistui. Vèliau „atopijos maršas“ arba „atopinis gyvenimo ciklas" esti susijęs su ịsijautrinimu įkvepiamiesiems ir kitiems alergenams $[15,16]$.

Odos infekcija palaiko ydingąji atopinio dermatito (egzemos) patogenezès ratą [6].

Atopinio dermatito diagnostikos metodai $[1,14]$ :

- Anamnezè.

- Ligonio apžiūra.

- Diagnostiniai tyrimai:

- alerginiai odos méginiai;

- bendrasis IgE kiekis kraujo serume; 
- alergenui specifinių IgE antikūnų kiekis kraujo serume;

- provokaciniai maisto mėginiai;

- odos biopsija (prireikus diferencinei diagnostikai).

Kadangi atopinis dermatitas (egzema) yra alerginè liga, pacientui turi būti atliekama alergijos diagnostika. Dažniausiai atliekami odos dūrio arba dūrio dūrio alerginiai odos mèginiai, kurie padeda nustatyti nuo IgE priklausomas alergines reakcijas. Literatūroje nurodoma, kad net pusei tirtu atopiniu dermatitu sergančiu vaiku alergija maistui pasireiškia lètojo tipo alerginemis reakcijomis [17]. Joms nustatyti naudojami odos lopo méginiai su maisto alergenais. Provokaciniai maisto méginiai tebèra „auksinis standartas" maisto alergijai patvirtinti [18]. Kiti nepatvirtinti tyrimai, kaip antai limfocituc citotoksiškumo, bazofilų degranuliacijos, serumo IgG (ar poklasių), diagnozuojant neturi būti atliekami [14].

Iki šiol atopiniam dermatitui diagnozuoti dažniausiai buvo naudojami klasikiniai didieji ir mažieji diagnostikos kriterijai pagal J. M. Hanifin ir G. Rajka (1980) arba Williams kriterijai. Pagal naujai peržiūrètus kriterijus, kuriuos atrenkant darbo grupejje dalyvavo ir J. M. Hanifin, skiriamos 3 pagrindinès grupès (1 lentelè) [3].

Atopini dermatitą galima diagnozuoti ir pagal Williams kriterijus [1]: niežẻjimas (ir/arba jo objektyvi išraiška - nukasymo žymès) bei kartu 3 iš šiu simptomu:

1. Lètinè dermatito eiga anamnezèje: lenkiamųjų paviršiu pažeidimas, vaikams iki 4 metu amžiaus veido ir tiesiamųjų paviršių pažeidimas;

2. Astma arba polinozé ligonio arba pirmos eilès giminiu anamnezèje (vaikams iki 4 metu amžiaus);

3. Generalizuotas odos sausumas paskutiniais metais

4. Objektyviai: lenkiamųjų sąnarinių paviršių bei kaklo odos egzema, o vaikams iki 4 metu - veido odos ir tiesiamųjų paviršiuc egzema.

5. Ankstyva pradžia (iki 2 metų amžiaus). Simptomas netaikomas vaikams iki 4 metu;

Atopinis dermatitas (egzema) pagal eigą skiriamas i 3 sunkumo laipsnius: lengvos, vidutinio sunkumo eigos, sunkios eigos. Sunkumo laipsnio objektyviam vertinimui taikomi ịvairūs indeksai $[1,3,19,20]$ :

- SCORAD (angl. Severity scoring of atopic dermatitis) indeksas;

- EASI (angl. Eczema Area and Severity Index) indeksas;

- OSAAD (angl. Ojective Severity Assessment of Atopic Dermatitis) indeksas.

Lietuvoje dažniausiai naudojamas SCORAD indeksas (modifikuotas pagal R. Kuzminskienę, 2004) [21], pagal kuri atopinio dermatito sunkumo laipsnis priklauso nuo balų skaičiaus:

- 1-24 balai - lengvas

- 25-50 baluc - vidutinis

- > 50 balų - sunkus

\section{ATOPINIO DERMATITO (EGZEMOS) GYDYMAS}

Gydymo tikslai [1, 15, 22, 23]:

1. Palaikyti normalų ligonio aktyvumą, miegą ir psichologinę būklę bei gyvenimo kokybę, išvengti varginančiu ligos simptomų.

2. Kontroliuoti ligos eigą, ligonio aplinką ir mitybą.

3. Vengti nepageidaujamo vartojamų vaistuc poveikio.

4. Išvengti astmos ir alerginès slogos.

5. Apmokyti ligonius ir jų artimuosius.
1 lentelè. NAUJAI PERŽIŨRETI ATOPINIO DERMATITO DIAGNOSTIKOS KRITERIJAI (MODIFIKUOTA PAGAL AMERIKOS DERMATOLOGŲ AKADEMIJOS INICIJUOTĄ TARPTAUTINI SUTARIMA, 2003, 2004 M.) [3, 19]

A. BÜTINI DIAGNOSTINIAI KRITERIJAI (privalomi)

1. Niežèjimas

2. Egzema (ūminè, poūmè, lètinè)

a) tipinè priklausoma nuo amžiaus morfologija:

- kūdikiams ir vaikams: veidas, kaklas, tiesiamieji rankų ir kojų paviršiai;

- bet kuriame amžiuje: lenkiamieji paviršiai

- nebūdinga: kirkšniu ir pažastú odos pažeidimai

b) lètinè ar banguojanti ligos eiga

B. SVARBŪS DIAGNOSTINIAI KRITERIJAI (papildomi, būdingi daugumai ligoniu)

1. Pradžia ankstyvame amžiuje

2. Atopija (pagal šiuolaikinę alergijos terminologiją privalomas atopinei egzemai) [8]:

a) asmeninè (gretutinès alerginès ligos) ir (arba) šeiminè (alerginès ligos šeimoje) anamnezé

b) IgE reaktyvumas

3. Kserozè

C. SUSIJE DIAGNOSTINIAI KRITERIJAI (pagalbiniai, nespecifiniai, padeda nustatyti diagnozę)

1. Atipiška kraujagyslių reakcija (pvz.: baltasis dermografizmas, veido blyškumas)

2. Folikulinė keratozè, padụ ir delnų paryškejjusios raukšlès, ichtiozė

3. Akiu (keratokonusas, priekinė subkapsulinė katarakta ir kt.), periorbitiniai pokyčiai (Dennie-Morgan raukšlès ir kt.)

4. Kitų sričių pokyčiai (pvz.: cheilitas, perioraliniai, periaurikuliariniai pažeidimai)

5. Lichenifikacija, niežulio pobūdžio pažeidimai

\section{Gydymo principai $[1,5]$ :}

1. Alergenų ir kitų provokuojančių veiksnių pašalinimas: dieta, aplinkos kontrolè.

2. Odos priežiūra ir barjerinès epidermio funkcijos atkūrimas emolientais.

3. Uždegimo slopinimas:

- geriamieji (prireikus) ar vietinio poveikio gliukokortikoidai;

- vietinio poveikio imunomoduliatoriai (kalcineurino inhibitoriai);

- geriamieji imunosupresantai (prireikus).

4. Niežulio slopinimas - geriamieji antihistamininiai ( $\mathrm{H}_{1}$ blokatoriai) vaistai.

5. Antrinès infekcijos profilaktika ar gydymas (vietinio poveikio ar geriamieji antibakteriniai vaistai, antivirusiniai vaistai).

6. Psichologo ar psichoterapeuto pagalba (prireikus). Pagal naujausius tarptautinius atopinio dermatito diagnostikos ir gydymo susitarimus [3, 14] rekomenduojamas pakopinis (kaip ir astmos) gydymas pagal ligos sunkumą ir ligos kontrolę. Dermatologai pritaikè „šviesoforo“ principą: išskyrè tris pakopas (1 pav.) [3]. Alergologų PRACTALL susitarime [14] skiriamos 4 pakopos: vien tik sausos odos bazinis gydymas emolientais (1 pakopa); lengvo/vidutinio sunkumo atopinio dermatito gydymas silpnais/vidutinio stiprumo vietinio poveikio gliukokortikoidais ir (arba) vietinio poveikio kalcineurino inhibitoriais (2 pakopa); vidutinio/sunkaus atopinio dermatito gydymas vidutinio stiprumo/ stipriais vietinio poveikio gliukokortikoidais ir (arba) vietinio poveikio kalcineurino inhibitoriais (3 pakopa); sunkaus atopinio dermatito gydymas sisteminio poveikio vaistais (pvz.: ciklosporinu A, antimikrobiniais vaistais, 


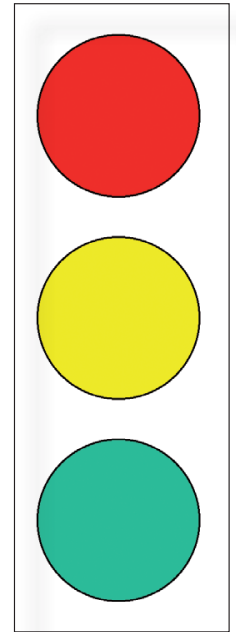

\section{Paūmèjimo gydymas}

Vietinio poveikio GKK + geriamieji antibiotikai +/- alt. (geriamieji GKK, fototerapija, ciklosporinas ir kt.) $+/-\mathrm{H}_{1}$ blokatoriai Emolientai Aukštesnioji palaikomojo ilgalaikio gydymo pakopa Pagrindas - vietinio poveikio KI (Pimecrolimus/Tacrolimus) arba epizodiškai vietinio poveikio $\mathrm{GKK}+/-\mathrm{H}_{1}$ blokatoriai Nepakankama kontrolè - vidutinio stiprumo vietinio poveikio GKK

Emolientai

\section{Aukštesnioji palaikomojo ilgalaikio gydymo pakopa} Pagrindas - vietinio poveikio KI (Pimecrolimus/Tacrolimus) arba epizodiškai vietinio poveikio $\mathrm{GKK}+/-\mathrm{H}_{1}$ blokatoriai Nepakankama kontrolè - vidutinio stiprumo vietinio poveikio GKK

Emolientai

1 pav. ATOPINIO DERMATITO GYDYMAS: PAKOPINIS VEIKSMŲ PLANAS (MODIFIKUOTA PAGAL TARPTAUTINI DIAGNOSTIKOS IR GYDYMO SUTARIMA, 2004 [3]

GKK - gliukokortikoidai, KI - kalcineurino inhibitoriai.

gliukokortikoidais ir kt.) (4 pakopa). Išskirtinis dėmesys skiriamas ligos paūmėjimu profilaktikai vartojant imunomoduliatorius - naujuosius vietinio poveikio kalcineurino inhibitorius (1 pav.). Šie nesteroidiniai preparatai veikia odos aktyvias $\mathrm{T}$ ląsteles, kurios gamina uždegimo procese dalyvaujančius citokinus, sukeliančius paraudimą, patinimą bei niežèjimą. Kalcineurino inhibitoriai (pimecrolimus, tacrolimus) blokuoja šiuc citokinų gamybą ir išsiskyrimą, todèl mažèja minèti uždegimo simptomai. Juos pradejjus vartoti, kai atsiranda pirmieji ligos simptomai, užkertamas kelias paūmëjimui [3, 24, 25, 26, 27]. Europos vaistų agentūros (EVA) Žmonèms skirtu vaistiniu preparatų komitetas, ivvertinęs saugumo duomenis, nustatè, kad vartojant šiuos preparatus, nauda didesnè nei rizika. Jie vartojami tik pagal patvirtintas indikacijas, vengiant ilgalaikio nepertraukiamo gydymo. Jei ligonio būklè nepagerèja per 2 savaites arba liga pasunkèja, reikia iš naujo peržiūrèti atopinio dermatito diagnozę ir spręsti dèl tolesnio gydymo. Preparatų negalima vartoti, kai yra odos piktybinių navikų ar ikivėžinių būklių tikimybè bei imunodeficito būklès pacientams.

\section{APIBENDRINIMAS}

Prieš skiriant atopinio dermatito (egzemos) gydymą, ivertinamas ne tik ligos sunkumo laipsnis, pažeistos odos apimtis, anamnezès duomenys, bet ir ligos įtaka šeimos gyvenimo kokybei bei psichologinè būklè Emolientu skiriama nuolatiniam nepertraukiamam vartojimui. Vietinio poveikio gliukokortikoidai ir kalcineurino inhibitoriai palaikomajam gydymui skiriami pertraukiamu (intermituojančiu) režimu. Esant sunkiai ligos eigai ir neefektyviam gydymui, sprendžiamas klausimas dèl stiprių vietinio poveikio gliukokortikoiduc, geriamųjų gliukokortikoidų, imunosupresantuc vartojimo ar fototerapijos. Gali prireikti psichologo ar psichoterapeuto pagalbos $[1,3]$. Slopinamojo poveikio antihistamininiai vaistai $\left(\mathrm{H}_{1}\right.$ blokatoriai) gali būti naudingi trumpalaikiam gydymui kartu su vietinio poveikio vaistais esant stipriam niežuliui. Neslopinančių antihistamininiu vaistuc poveikis esti vidutinis. Klinikinių tyrimų duomenų apie naujausių neslopinančių antihistamininių vaistų veiksmingumą gydant atopini dermatitą nèra [14].
Laiku pradedamo atopinio dermatito (egzemos) gydymo ir geros ligos kontrolès reikšmè:

- gera ligos prognozé;

- antrinès infekcijos profilaktika;

- astmos profilaktika;

- geresné paciento ir jo šeimos narių gyvenimo kokybè.

\section{ATOPIC DERMATITIS}

\section{REGINA ĖMUŽYTE்}

CLINIC OF CHILDREN DISEASES

VILNIUS UNIVERSITY

Key words: atopic dermatitis, atopic eczema, diagnosis, treatment. Summary. Atopic dermatitis (eczema) is a highly pruritic, chronic inflammatory skin disease, that commonly presents during early infancy and childhood, and currently affects $10-20 \%$ of children worldwide. There is a significant burden of disease and its impact on the quality of life of the child and his family. The evolution of understanding of the pathogenesis and therapeutic alternatives of atopic dermatitis (eczema) is useful in improving the control of disease over a longterm basis. This paper reviews new data on diagnosing and terminology of atopic dermatitis. The clinically useful recommendations for the treatment based upon disease severity are presented, pointing out the importance of prevention, application of emollients and new anti-inflammatory topical treatment with calcineurin inhibitors.

\section{LITERATŪRA}

1. Ėmužytè R, Dubakienè R, Kuzminskienè R, Šuliokienè N, Čeburkovas O, Leišytè P. ir kt. Atopinio dermatito diagnostika ir gydymas. Metodinè mokomoji medžiaga - sutarimas. Alergologija ir klinikinè imunologija 2003, 2(1) : 41- 59.

2. Asher MI, Montefort S, Bjorksten B, Lai CK, Strachan DP, Weiland SK et al. Worldwide time trends in the prevalence of symptoms of astma, allergic rhinoconjunctivitis, and egzema in childhood: ISAAC Phases One and Three repeat multicountry cross-sectional surveys. Lancet 2006; 368: 733-743.

3. Eichenfield LF. Consensus guidelines in diagnosis and treatment of atopic dermatitis. Allergy 2004; 59(78): 86-92.

4. Ėmužytè R. Atopinis dermatitas. Vaiko priežiüros ir ligu žinynas, I dalis (A-L) / Vyriausiasis redaktorius LMA narys korespondentas, prof., habil.dr. Vytautas Basys. - Vilnius: Mokslo ir enciklopediju leidybos institutas, 2005. - $296 \mathrm{p}$.

5. Ėmužytè R, Šuliokiené N. Atopinis dermatitas. Vaikų ligos, 4 tomas Parengta vadovaujant prof., habil. dr. Algimantui Raugalei. - Vilnius: Vilniaus universiteto leidykla, 2005, $62 \mathrm{p}$.

6. Cork MJ. The importance of skin barier function. Journal of Dermatological treatment 1997; 8(1).

7. EAACI Position paper. A revised nomenclature for allergy. Allergy 2001; 56:813-824.

8. Revised Nomenclature for Allergy for Global use: Report of the Nomenclature Review Committee of the World Allergy Organization / S.G.O Johansson and others. J Allergy Clin Immunol 2004; 113(5): 832-6.

9. Ėmužytė R. "Neatopinis" atopinis vaiku dermatitas - ar gali būti? Alerginès odos ligos: dabartis ir perspektyvos. Resp. mokslinès praktinès konferencijos medžiaga(straipsniai, sutarimai), Vilnius, 2004:28-32.

10. Ėmužytè R. Neatopinis vaikų atopinis dermatitas versus atopinis dermatitas. Vaiku pulmonologija ir alergologija $2004 ; 7(1): 2461-2467$.

11. Akdis CA, Akdis M. Immunological differences between intrinsic and extrinsic types of atopic dermatitis. Clin Exp Allergy 2003; 33: 1618-21.

12. Ėmužyte R. Skirtingi atopinio vaiku dermatito fenotipai. Alergologija ir klinikinè imunologija 2003; 2(1): 25-32.

13. Wollenber A, Bieber T. Atopic dermatitis: from the genes to skin lesions Allergy 2005; 55: 205-213.

14. Akdis CA, Akdis M, Bieber T, Bindslev-Jensen C, Boguniewicz M, Eigenmann $P$ et al. Diagnosis and treatment of atopic dermatitis in children and adults: European Academy of Allergology and Clinical Immunology/ American Academy of Allergy, Asthma and Immunology/ PRACTALL Consensus Report. Review article. Allergy 2006; 61: 969-987.

15. Wahn U. Atopic dermatitis: a review. In: Guidelines for treatment of allergic skin disorders. Cheshire; Adelpni Communications Ltd. 1995: 13-8. 